\title{
Effect of Perkinsus qugwadi on various species and strains of scallops
}

\author{
Susan M. Bower ${ }^{1, *}$, Janice Blackbourn ${ }^{2}$, Gary R. Meyer ${ }^{1}$, David W. Welch ${ }^{1}$ \\ ${ }^{1}$ Department of Fisheries and Oceans, Pacific Biological Station, Nanaimo, British Columbia V9R 5K6, Canada \\ ${ }^{2}$ Island Scallops Ltd, 5552 West Island Hwy, Qualicum Beach, British Columbia V9K 2C8, Canada
}

\begin{abstract}
Japanese scallops Patinopecten yessoensis, introduced into British Columbia, Canada, as a species for aquaculture, proved highly susceptible to an enzootic protistan parasite Perkinsus qugwadi (initially called SPX). Sporadic occurrence of the parasite among cultured scallops sometimes resulted in losses exceeding $90 \%$. Native scallops (Chlamys rubida and Chlamys hastata) were resistant to infection and the pathogenic effects of the parasite. Weathervane scallops Patinopecten caurnus (not amenable to culture but closely related to the Japanese scallop) were not available to test for resistance to infection. Laboratory and field studies showed that first-generation progeny of Japanese scallops that survived an epizootic outbreak of $P$. qugwadi had a significant increase in resistance to infection and resulting mortalities. Hybrid scallops, resulting from a cross between Japanese scallop females (from the same group of scallops that survived an epizootic outbreak of $P$. qugwadi) and weathervane scallop males, had similar resistance to $P$. qugwadi. The identification of scallop stocks that are resistant to $P$. qugwadi has facilitated the development of a scallop culture industry in British Columbia.
\end{abstract}

KEY WORDS: Perkinsus qugwadi - Patinopecten yessoensis - Scallops - Disease - Resistance

\section{INTRODUCTION}

The protistan Perkinsus qugwadi Blackbourn, Bower, Meyer, 1998, initially called SPX (scallop protistan $X$ ), is a lethal pathogen of the Japanese scallop Patinopecten yessoensis (Jay, 1856) cultured in British Columbia, Canada (Blackbourn et al. 1998). This parasite sporadically caused epizootic disease among cultured scallops at some locations, resulting in mortalities that approached $100 \%$ among Japanese scallops less than 1 yr of age $(<5 \mathrm{~cm}$ in shell height). Mortalities among older (about 2 yr of age) and larger Japanese scallops (about $9 \mathrm{~cm}$ in shell height) were less severe, up to $60 \%$. Surviving Japanese scallops often had pustule-like lesions in all organs, including the adductor muscle (Bower et. al. 1998). The unpredictable occurrence of this parasite and resulting high mortalities jeopardised the success of the scallop culture industry in British Columbia.

During the spring of 1994 at one grow-out location, mortalities attributable to Perkinsus qugwadi ap-

-E-mail: bowers@dfo-mpo.gc.ca proached $100 \%$ among cultured Japanese scallops (5.0 $\pm 0.4 \mathrm{~cm}$ shell height) and all survivors that were examined ( $\mathrm{n}=8$ ) were infected with $P$. qugwadi. When the extent of the mortalities was being assessed, a few specimens of native swimming scallops Chlamys spp., originating from a natural set, were found within the lantern nets among the dead Japanese scallops. There was no evidence that any of the native species of scallops had experienced mortalities (no empty shells nor moribund individuals were observed) and none of the native scallops examined histologically (C. rubida, $\mathrm{n}=18$, mean shell height of $3.0 \pm 0.6 \mathrm{~cm}$; and $C$. hastata, $\mathrm{n}=1$, shell height of $5.5 \mathrm{~cm}$ ) were infected with $P$. qugwadi. This observation indicated that some scallops were resistant to infection by $P$. qugwadi and led to the speculation that the severe impact of $P$. qugwadi on the developing scallop culture industry could be curtailed by the selection and breeding of scallops.

In an effort to circumvent losses due to this parasite, laboratory and field studies were set up to investigate the resistance of various species and strains of scallop to Perkinsus qugwadi. Initially, the resistance of Chlamys spp. to P. qugwadi was confirmed in a labora- 
tory challenge experiment. Another laboratory challenge experiment was set up to assay the resistance of progeny of Japanese scallops (cohort named S10) that survived a $P$. qugwadi epizootic at the Denman Island (Baynes Sound) culture site in 1992 and a hybrid of S10 females crossed with weathervane scallop (a related, native species) Patinopecten caurinus (Gould, 1850) males. The results of the laboratory experiments were confirmed by field exposure studies conducted at several grow-out locations in British Columbia.

\section{MATERIALS AND METHODS}

An initial laboratory study was set up to confirm the resistance of Chlamys spp. to infection by Perkinsus qugwadi. Fifteen $C$. hastata $(6.4 \pm 0.4 \mathrm{~cm}$ in shell height) and 15 C. rubida (5.9 $\pm 0.1 \mathrm{~cm}$ in shell height) obtained from the commercial fishery and 15 Japanese scallops (5.5 $\pm 0.6 \mathrm{~cm}$ in shell height) obtained from a stock with no known previous exposure to $P$. qugwadi were inoculated into the adductor muscle with $50 \mu \mathrm{l}$ containing about $4 \times 10^{4}$ vegetative stages but no zoospores of $P$. qugwadi. The parasite inoculum was prepared as described by Bower et al. (1998) from 6 Japanese scallops that had been infected in the laboratory by inoculation $9 \mathrm{wk}$ earlier. Inoculated scallops were maintained in the laboratory in $50 \mathrm{l}$ tanks supplied with flowing sea water ( 2 to $41 \mathrm{~min}^{-1}$ ) of ambient salinity (28 to $30 \mathrm{ppt}$ ) and temperatures (from 10 to $12^{\circ} \mathrm{C}$ ). They were fed 3 to 5 times per week with a variety of cultured algae (i.e. from 2 to $4 \mathrm{l}$ containing about $6 \times 10^{6}$ cells $\mathrm{ml}^{-1}$ of Chaetoceros gracilis [clone NRC 108], Isochrysis sp. from Tahiti [clone Bigalow CCMP1324], or 3H Thalassiosira pseudonana [clone Bigalow
CCMP1335]). Every 2 to $4 \mathrm{~d}$ all scallops were examined and weak or dead individuals were removed. Scallops that were not too decomposed were examined microscopically for $P$. qugwadi. The experiment was terminated on Day 57 and all surviving scallops were examined histologically for $P$. qugwadi. The intensity of infection was categorised according to definitions presented in Table 1. To date, histology is the most sensitive method known for detecting infection. $P$. qugwadi does not give a positive response to the thyoglycolate test (Ray 1966) used for detecting other species of Perkinsus (Bower et al. 1998).

A second laboratory exposure experiment was conducted with 3 stocks of scallops: (1) naive Japanese scallops $(4.9 \pm 0.5 \mathrm{~cm}$ in shell height) derived from broodstock (49 females/11 males) thought never to have been exposed to Perkinsus qugwadi, (2) selected Japanese scallops $(4.3 \pm 0.4 \mathrm{~cm}$ in shell height) derived from broodstock (cohort S10, 115 females/35 males) that were survivors of a $P$. qugwadi epizootic event and (3) hybrid scallops $(5.0 \pm 0.4 \mathrm{~cm}$ in shell height) resulting from a cross between S10 Japanese scallop females ( $n=68$ ) and weathervane scallop males ( $n=$ about 14 ). All 3 stocks were produced at a commercial bivalve hatchery (Island Scallops Ltd, 5552 West Island Hwy, Qualicum Beach, B.C., Canada) in the spring of 1994 and grown for about 8 mo at a location that rarely has scallops infected by $P$. qugwadi (Cypress Bay, see Fig. 1). About 70 scallops of each stock were placed in the laboratory about 1 mo prior to initiating the exposure experiment. On the day of experimental initiation, $P$. qugwadi was isolated as described by Bower et al. (1998) from the gonad, mantle and gills of 16 Japanese scallops that had been infected in the laboratory $10 \mathrm{wk}$ earlier. About 20 scallops from each stock were inocu-

Table 1. Definitions of categories for the intensity of infection of Perkinsus qugwadi in scallops ascertained by the examination of histological sections of scallops magnified 250 times with a microscope field diameter of $700 \mu \mathrm{m}$

\begin{tabular}{|c|c|c|c|}
\hline Category & $\begin{array}{l}\text { No. of parasites } \\
\text { per field }\end{array}$ & $\begin{array}{l}\text { Scallop organs } \\
\text { usually infected }\end{array}$ & $\begin{array}{l}\text { Presence of associated } \\
\text { haemocyte accumulations }\end{array}$ \\
\hline Not found (NF) & $\begin{array}{l}\text { No } P \text {. qugwadi found on } \\
\text { entire histological section } \\
\text { containing all major organs }\end{array}$ & None & None \\
\hline Light (L) & $\begin{array}{l}<5 \text {, in a few focal patches with } \\
\text { most of tissue free of infection }\end{array}$ & $\begin{array}{l}\text { Gonad and digestive gland, usually } \\
\text { adjacent to the intestinal tract }\end{array}$ & Yes \\
\hline Moderate (M) & $\begin{array}{l}5 \text { to } 20 \text {; focal patches greater in } \\
\text { diameter and/or more abundant } \\
\text { than above }\end{array}$ & $\begin{array}{l}\text { As above, occasionally in sinuses } \\
\text { of adductor muscle and rarely in } \\
\text { gills and kidney }\end{array}$ & Usually \\
\hline Heavy $(\mathrm{H})$ & 20 to several hundred & $\begin{array}{l}\text { In connective tissue of all organs with } \\
\text { greatest accumulations in gonad and } \\
\text { digestive gland }\end{array}$ & $\begin{array}{l}\text { Rarely, infection usually } \\
\text { systemic, see Figs. } 2 \& 3\end{array}$ \\
\hline Very heavy (VH) & $\begin{array}{l}\text { Overwhelming, more parasite } \\
\text { cells than host tissue in gonad } \\
\text { and digestive gland, see Fig. } 4\end{array}$ & As above & No \\
\hline
\end{tabular}




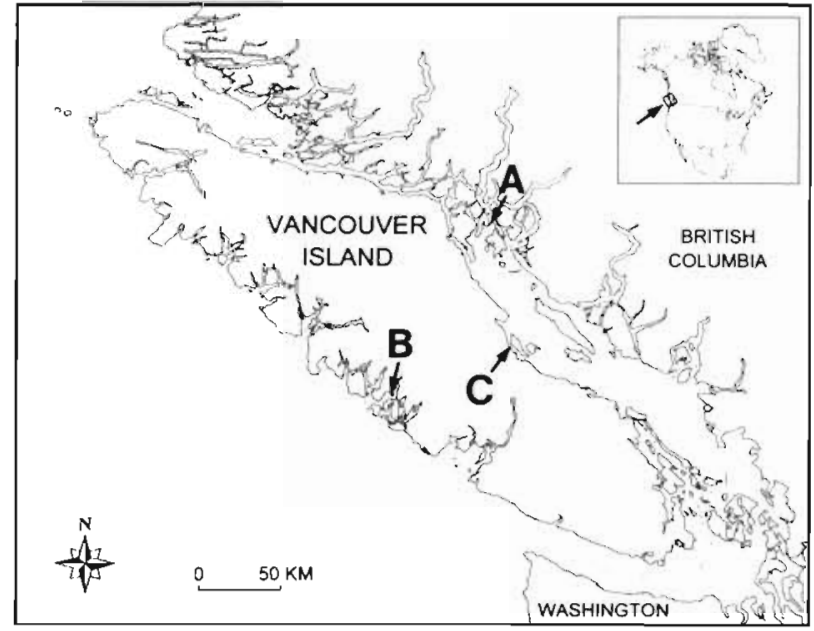

Fig. 1. Locations of commercial scallops culture sites in British Columbia, Canada, from which Patinopecten sp. were obtained. A: Whale Passage, B: Cypress Bay, C: Baynes Sound

lated into the adductor muscle with $100 \mu \mathrm{l}$ of 1 of the following: undiluted isolate (containing about $1 \times 10^{4}$ vegetative stages and about $1 \times 10^{5}$ zoospores of $P$. qugwadi per scallop), a $1 / 10$ dilution of the isolate in filtered $(0.22 \mu \mathrm{m})$ ambient sea water, or only filtered sea water (controls). The inoculated scallops were maintained in the laboratory for $69 \mathrm{~d}$ after inoculation and examined as described above. This experiment was intentionally terminated prior to the expected onset of mortalities caused by $P$. qugwadi in order to obtain comparable information on the prevalence and intensity of infection between the stocks.

Statistical analysis of the results of the second laboratory exposure experiment required the use of methods that explicitly account for the binomial nature of the observations. The use of generalised linear models (GLIM) was appropriate because the proportion of infected scallops could vary only between 0 and 1 , and the uncertainty in the observations was binomially distributed (McCullagh \& Nelder 1989, Hastie \& Pregibon 1992). The data was analysed with GLIM via the statistical package S-Plus, and the fits of different analyses compared using likelihood ratio tests. Results were deemed statistically significant at the $p=0.05$ level.

The same 3 stocks of scallops were also used in field exposure trials to substantiate the results obtained in the laboratory exposure experiments. In late October 1994 , about 300 scallops from each stock were distributed to each of 3 commercial grow-out facilities located in: Whale Passage, Cypress Bay and Baynes Sound (Fig. 1). Beginning in December 1994 and at about 1 mo intervals thereafter until February 1996, about 20 scallops of each stock from each location were examined by histology for Perkinsus qugwadi.
All scallops were prepared for histological examination by first removing the soft tissues from the shell. Each scallop was dissected to preserve the digestive gland intact, and a portion of the gonad, kidney, adductor muscle, gills and mantle. All tissues were fixed in Davidson's solution (Shaw \& Battle 1957) and embedded in paraffin wax. Five micron sections were cut, stained with Harris's modified hematoxylin and $0.5 \%$ alcoholic eosin, and examined using a light microscope (100 to $1000 \times$ magnification).

\section{RESULTS}

The exposure of Chlamys spp. to Perkinsus qugwadi in the laboratory confirmed the resistance of these species to infection. During the laboratory incubation period following the inoculation of $P$. qugwadi, $6 \mathrm{C}$. hastata (1 each on Days 41, 45, 48, 49, 52 and 55), 2 C. rubida (on Days 51 and 55) and 10 Japanese scallops (on Days 43, 49, 51 [2], 52 [3], 55 and 56 [2]) died. None of the Chlamys spp. and all Japanese scallops were infected with $P$. qugwadi. When the experiment was terminated on Day 57, none of the remaining 9 C. hastata were infected and 2 of the remaining 13 C. rubida had light infections. Four of the remaining 5 Japanese scallops were infected. The intensity of infection in the 14 Japanese scallops was light in 1 scallop, moderate in 4 , heavy in 5 and very heavy in 4 other individuals (see Table 1 for definitions of infection intensity). None of the 40 uninoculated Japanese scallops, from the same source, were infected with $P$. qugwadi.

Exposure of the 3 scallop stocks to Perkinsus qugwadi in the second laboratory experiment indicated that the hybrid stock and the selected stock were more resistant to infection than the naive stock (Table 2). During the $69 \mathrm{~d}$ incubation period, a total of 15 scallops were found moribund or recently dead (12 succumbed within $10 \mathrm{~d}$ of inoculation, probably as a consequence of toxic products in the undiluted inoculum) and all but 3 were examined histologically for $P$. qugwadi. Only 1 was infected with $P$. qugwadi-a scallop from the naive stock that was found moribund on Day 43 had a light intensity of infection.

On termination of the experiment, the prevalence and intensity of Perkinsus qugwadi in surviving scallops differed both among stocks and with abundance of parasites contained in the inoculum (Table 2). The absence of $P$. qugwadi in all of the scallops inoculated with filtered sea water indicates that the prevalence of the parasite in each of the stocks before inoculation was very low. We therefore excluded the filtered seawater control results from further analysis, in order to evaluate the effect parasite abundance in the inoculum (inoculum strength) had on the prevalence of infection. 
Table 2. Prevalence and intensity of infection with Perkinsus qugwadi in 2 stocks of Patinopecten yessoensis and a hybrid between $P$. yessoensis females and Patinopecten caurinus males $69 \mathrm{~d}$ after exposure by inoculation with the parasite in the laboratory. See Table 1 for definitions of the intensity of infection

\begin{tabular}{|c|c|c|c|c|c|c|c|c|c|}
\hline \multirow[t]{2}{*}{$\begin{array}{l}\text { Scallop } \\
\text { stock }\end{array}$} & \multirow[t]{2}{*}{ Inoculum } & \multirow[t]{2}{*}{$\begin{array}{c}\text { No. } \\
\text { inoculated }\end{array}$} & \multirow{2}{*}{$\begin{array}{c}\text { No. } \\
\text { survived } \\
\text { to Day } 69\end{array}$} & \multirow[t]{2}{*}{$\begin{array}{c}\text { Prevalence }(\%) \\
\text { in survivors }\end{array}$} & \multicolumn{5}{|c|}{$\begin{array}{l}\text { No. of survivors with } \\
P . \text { qugwadi intensity of: }\end{array}$} \\
\hline & & & & & VH & $\mathrm{H}$ & $M$ & L & $\mathrm{NF}$ \\
\hline Naive & & 21 & 17 & $100^{a}$ & 8 & 4 & 4 & 1 & 0 \\
\hline Selected & Isolate & 20 & 15 & 73 & 0 & 4 & 5 & 2 & 4 \\
\hline Hybrid & Undiluted & 21 & 16 & 69 & 0 & 3 & 3 & 5 & 5 \\
\hline Naive & & 22 & 22 & 91 & 3 & 8 & 8 & 1 & 2 \\
\hline Selected & Isolate & 21 & 21 & 71 & 0 & 3 & 8 & 4 & 6 \\
\hline Hybrid & $1 / 10$ dilution & 21 & 21 & 43 & 0 & 1 & 2 & 6 & 12 \\
\hline Naive & Filtered & 20 & 19 & 0 & 0 & 0 & 0 & 0 & 19 \\
\hline Selected & Sea water & 20 & 20 & 0 & 0 & 0 & 0 & 0 & 20 \\
\hline Hybrid & (Control) & 20 & 20 & 0 & 0 & 0 & 0 & 0 & 20 \\
\hline
\end{tabular}

${ }^{2}$ The zoospore stage of $P$. qugwadi developed in 5 of the naive stock inoculated with the undiluted isolate. All scallops with zoospores had heavy to very heavy intensities of infection

To assess the relative importance of scallop stock and inoculum strength on prevalence, we fit GLIM models as a function of stack alone, and as a function of stock and inoculum strength. The results were compared relative to the fully saturated model containing terms for stock, inoculum strength, and their interaction. (For this model, the fit was perfect and there were no remaining degrees of freedom.) The inclusion of stock as an explanatory variable was statistically significant, and the subsequent inclusion of inoculum strength did not improve the overall fit of the model sufficiently to reject the null hypothesis that differences in stock alone explained the pattern of prevalence. The results therefore indicate that the naive stock was most susceptible to infection with Perkinsus qugwadi and that the differences in inoculum strength had only a small influence on the parasite prevalence at the end of the experiment. The latter point is significant because a $23 \%$ mortality rate was observed in scallops challenged with full strength inoculum, and a zero mortality rate was observed with the use of diluted inoculum. Also, only 5 scallops, all of the naive stock that received the undiluted inoculum, had infections sufficiently advanced for the production of zoospores.

Both the selected and hybrid stocks showed a significantly lower prevalence than the naive stock. To examine the relative resistance of the hybrid and selected stocks, we combined the data for the full strength and diluted inoculates, and compared the respective prevalence rates $(26 / 36=72 \% ; 20 / 37=54 \%)$. Although the hybrid stock appeared more resistant to infection than the selected stock, the difference was not statistically significant. (Similar results were obtained when the response of the 2 stocks was compared using the results from either of the experiments using the full-strength and diluted inoculum.)
Field study results confirmed that the selected stock and hybrid scallops were more resistant to infection than the naive stock (Table 3). All scallops were about $2.5 \mathrm{~cm}$ in shell height at the beginning of the field study in December 1994 and survivors grew to about $10.0 \mathrm{~cm}$ in shell height by February 1996, when the sampling was terminated. There were no marked differences in the rate of growth or soft tissue condition among the 3 stocks at each location. Although infection with Perkinsus qugwadi was first detected earlier at one of the locations (in February at Whale Passage and in May at Cypress Bay and Baynes Sound), infection consistently appeared first in the naive stock. Of the 762 scallops examined from Cypress Bay, only 2 individuals, both from the naive stock, were found infected (in both cases the intensity of infection was light). Of the 763 scallops examined from Baynes Sound, 23 of the 25 infected scallops belonged to the naive stock. The intensity of infection in the naive scallops was heavy in 1, moderate in 4 individuals and light in 18 scallops, while the 2 other infected scallops were hybrids and both had light infections.

In scallops from Whale Passage, the prevalence and intensity of Perkinsus qugwadi infections in all scallops was much higher than at the other 2 locations. The parasite was first detected in subsamples of the naive scallops in February. By May, $89 \%$ of the naive scallops were infected and no further samples were available from this group because of the high mortalities attributed to $P$. qugwadi infection. The parasite was first detected in the other stocks at this location a month (selected stock) or two later (hybrids), and sufficient scallops from these 2 stocks survived to meet sampling requirements until December 1995. The intensity of infection was also heavier in naive scallops than in scallops of the other 2 stocks (Table 4 ). 
Table 3. Prevalence (\%) of Perkinsus qugwadi in 2 stocks of cultured Patinopecten yessoensis and a hybrid between $P$. yessoensis females and Patinopecten caurinus males (sample size in parentheses) placed at 3 commercial scallop culture facilities in British Columbia (see Fig. 1) in late October 1994 and examined at about 1 mo intervals until specimens were no longer available. -: samples not available for examination

\begin{tabular}{|c|c|c|c|c|c|c|c|c|c|c|}
\hline \multirow{2}{*}{\multicolumn{2}{|c|}{$\begin{array}{l}\text { Month } \\
\text { sampled }\end{array}$}} & \multicolumn{3}{|c|}{ Cypress Bay } & \multicolumn{3}{|c|}{ Baynes Sound } & \multicolumn{3}{|c|}{ Whale Passage } \\
\hline & & Naive & Selected & Hybrid & Naive & Selected & Hybrid & Naive & Selected & Hybrid \\
\hline 1994 & Dec & $0(20)$ & $0(19)$ & $0(20)$ & $O(16)$ & $0(19)$ & $0(18)$ & $0(21)$ & $0(14)$ & $0(19)$ \\
\hline \multirow[t]{10}{*}{1995} & Jan & $0(20)$ & $0(20)$ & $0(20)$ & $0(16)$ & $0(18)$ & $O(19)$ & $0(20)$ & $0(20)$ & $0(20)$ \\
\hline & Feb & $0(20)$ & $0(20)$ & $0(20)$ & $0(17)$ & $0(20)$ & $0(20)$ & $25(20)$ & $0(20)$ & $0(20)$ \\
\hline & Mar & 0 (19) & $0(20)$ & $0(20)$ & $0(20)$ & $0(20)$ & $0(20)$ & 50 (18) & $15(20)$ & $0(20)$ \\
\hline & Apr & $0(18)$ & $0(20)$ & $0(20)$ & $0(20)$ & $O(20)$ & $0(20)$ & $62(21)$ & $45(20)$ & $22(18)$ \\
\hline & May & $8(13)$ & $0(18)$ & $0(20)$ & $22(18)$ & $O(20)$ & $0(20)$ & 89 (18) & $45(20)$ & $54(13)$ \\
\hline & Jun/Jul & $5(20)$ & $0(20)$ & $0(32)$ & $14(21)$ & $0(20)$ & $5(20)$ & - & $36(28)$ & $10(30)$ \\
\hline & Aug & $0(20)$ & $0(20)$ & $0(19)$ & $10(20)$ & $0(22)$ & $0(20)$ & - & $25(20)$ & $35(20)$ \\
\hline & Sep & $0(20)$ & $O(20)$ & $0(20)$ & $0\{20\}$ & $0(20)$ & $0(20)$ & - & $10(20)$ & $5(20)$ \\
\hline & Oct & $0(19)$ & $0(17)$ & $0(16)$ & 16 (19) & $0(19)$ & $0(20)$ & - & $0(11)$ & $12(26)$ \\
\hline & Dec & $0(18)$ & $0(20)$ & $0(20)$ & $20(20)$ & $0(20)$ & $0(20)$ & - & $30(20)$ & $5(20)$ \\
\hline \multirow[t]{2}{*}{1996} & Jan & $O(17)$ & $0(20)$ & $0(20)$ & $29(21)$ & $0(20)$ & $5(20)$ & - & - & - \\
\hline & Feb & $0(18)$ & $0(19)$ & $0(20)$ & $5(20)$ & $0(20)$ & $0(20)$ & - & - & - \\
\hline \multicolumn{2}{|c|}{$\begin{array}{l}\text { Overall prevalence } \\
\text { (total examined) }\end{array}$} & $\begin{array}{c}0.8 \\
(242)\end{array}$ & $\begin{array}{c}0 \\
(253)\end{array}$ & $\begin{array}{c}0 \\
(267)\end{array}$ & $\begin{array}{c}9.3 \\
(248)\end{array}$ & $\begin{array}{c}0 \\
(258)\end{array}$ & $\begin{array}{c}0.8 \\
(257)\end{array}$ & $\begin{array}{l}36.4 \\
(118)\end{array}$ & $\begin{array}{l}20.7 \\
(213)\end{array}$ & $\begin{array}{c}11.5 \\
(226)\end{array}$ \\
\hline
\end{tabular}

In general, Japanese scallops of the selected and hybrid stocks developed a more intense haemocytic response to infection with Perkinsus qugwadi than Japanese scallops of the naive stock. The most marked difference was in scallops with a heavy intensity of infection (as defined in Table 1). In heavily infected scallops with an accumulation of haemocytes (Fig. 2) and in those without a haemocytic reaction (Fig. 3), the numbers of P. qugwadi per field (700 $\mu \mathrm{m}$ in diameter) were similar. However, in scallops with a haemocytic response, the $P$. qugwadi tended to be congregated into clusters and were embedded in accumulations of numerous haemocytes, whereas scallops without a haemocytic reaction had $P$. qugwadi dispersed throughout the connective tissue of most organs. In the combined results from the laboratory and field studies, 8 of the 16 selected and hybrid scallops with a heavy intensity of infection had an accumulation of haemocytes in association with the parasite, while only 2 of 20 heavily infected naive scallops had a haemocytic response. Of the 57 scallops with a moderate intensity of infection (25 naive, 22 selected and 10 hybrid scallops), only 1 scallop from the laboratory study did not have an accumulation of haemocytes around $P$. qugwadi and this scallop was from the naive stock. All scallops with a light intensity of infection ( $\mathrm{n}=113$ ) had an accumulation of haemocytes around the parasite(s) and the infections were confined to the focal tissue responses. Conversely, all 17 scallops (16 naive and 1 selected) with a very heavy intensity of infection (Fig. 4) had no evidence of a haemocyte reaction to the parasite.

Table 4. Number of scallops sampled from Whale Passage between February and December 1995 from 2 stocks of cultured Patinopecten yessoensis (a naive stock with no history of exposure to Perkinsus qugwadi and a selected stock that were progeny of survivors of a $P$. qugwadi epizootic) and a hybrid between $P$. yessoensis females ( $P$. qugwadi epizootic survivors) and Patinopecten caurinus males, with intensities of $P$. qugwadi infections as described in Table 1. -: samples not available for examination

\begin{tabular}{|c|c|c|c|c|c|c|c|c|c|c|c|c|c|c|c|}
\hline \multirow{2}{*}{$\begin{array}{l}\text { Month } \\
\text { sampled }\end{array}$} & \multicolumn{5}{|c|}{ Naive } & \multicolumn{5}{|c|}{ Selected } & \multicolumn{5}{|c|}{ Hybrid } \\
\hline & VH & $\mathrm{H}$ & $M$ & $\mathrm{~L}$ & NF & $\mathrm{VH}$ & $\mathrm{H}$ & $M$ & $\mathrm{~L}$ & NF & VH & $\mathrm{H}$ & $\mathrm{M}$ & $\mathrm{L}$ & $N F$ \\
\hline Feb & 0 & 0 & 1 & 4 & 15 & 0 & 0 & 0 & 0 & 20 & 0 & 0 & 0 & 0 & 20 \\
\hline Mar & 0 & 0 & 1 & 8 & 9 & 0 & 0 & 0 & 3 & 17 & 0 & 0 & 0 & 0 & 20 \\
\hline Apr & 3 & 3 & 3 & 4 & 8 & 0 & 1 & 4 & 4 & 11 & 0 & 1 & 2 & 1 & 14 \\
\hline May & 2 & 4 & 4 & 6 & 2 & 1 & 1 & 2 & 5 & 11 & 0 & 1 & 1 & 5 & 6 \\
\hline Jun/Jul & - & - & - & - & - & 0 & 1 & 1 & 8 & 18 & 0 & 0 & 0 & 3 & 27 \\
\hline Aug & - & - & - & - & - & 0 & 0 & 0 & 5 & 15 & 0 & 0 & 2 & 5 & 13 \\
\hline Sep & - & - & - & - & - & 0 & 0 & 0 & 2 & 18 & 0 & 0 & 0 & 1 & 19 \\
\hline Oct & - & - & - & - & - & 0 & 0 & 0 & 0 & 11 & 0 & 0 & 0 & 3 & 23 \\
\hline Dec & - & - & - & - & - & 0 & 0 & 2 & 4 & 14 & 0 & 0 & 0 & 1 & 19 \\
\hline
\end{tabular}



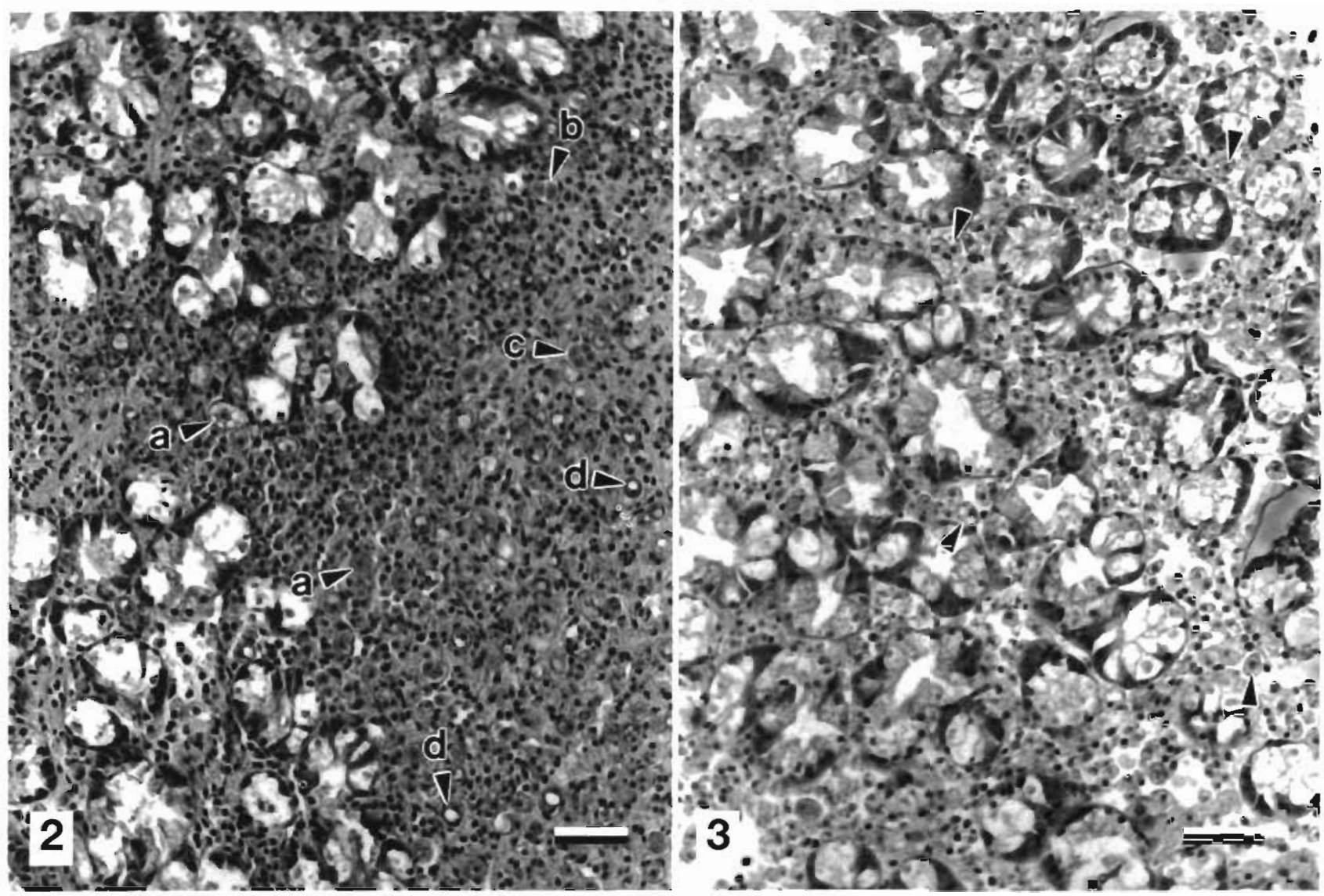

Figs. 2 \& 3. Patinopecten yessoensis infected with Perkinsus qugwadi. Histological sections (stained with hematoxylin and eosin) of the digestive gland of scallops heavily infected with $P$. qugwadi (a: single cell stage, b: 2 cell stage, c: 4 cell stage and d: 'signet ring' stage). The scallop illustrated in Fig. 2 had an intense haemocytic accumulation associated with $P$. qugwadi while the scallop illustrated in Fig. 3 showed no haemocyte response to the infection and only single cell stages of the parasite (arrows) are present. Scale bars $=50 \mu \mathrm{m}$

\section{DISCUSSION}

Perkinsus qugwadi is believed to be enzootic to British Columbia (B.C.) but the natural host(s) are unknown (Bower et al. 1998). Prior to the culture of Japanese scallops in the province, the parasite was undiscovered but proved to cause significant disease among Japanese scallops during development of the scallop farming industry in B.C. (Saunders \& Heath 1994). The resistance to infection demonstrated by native Chlamys spp. was not surprising because these species inhabit areas where the parasite naturally occurs. Unfortunately, weathervane scallops (also native to B.C.) were not available for challenge experiments to assess their resistance to $P$. qugwadi.

The weathervane scallop is relatively rare in B.C. and production of weathervane scallop juveniles in the scallop hatchery was limited precluding commercial culture of this species. The taxonomic relationship between the weathervane (occupying the northeast coast of the Pacific Ocean) and Japanese scallops (originat- ing on the northwestern Pacific coast) is controversial. Grau (1959) proposed that these scallops were subspecies within the same subgenus of Pecten and designated them as Pecten (Patinopecten) caurinus and $P$. $(P$.) caurinus yessoensis, respectively. Patinopecten has been raised to genus level, but some authors now propose that the Japanese scallop not only belongs in a different genus (Mizuhopectin) but also to a different subfamily (Motavkin 1986, Silina et al. 1988). Other authors have maintained these scallops as 2 species within the genus Patinopecten (i.e. Bernard 1983, Bernard et al. 1993). Nevertheless, the weathervane and Japanese scallops were hybridised but only the cross between Japanese scallop females and weathervane scallop males resulted in the production of sufficient juveniles for commercial culture (Saunders \& Heath 1994).

To verify that the cross resulted in hybrids, scallops were sent to Dr Ellen Kenchington (Department of Fisheries and Oceans, Bedford Institute of Oceanography, PO Box 1006, Dartmouth, Nova Scotia B2Y 4A2, 


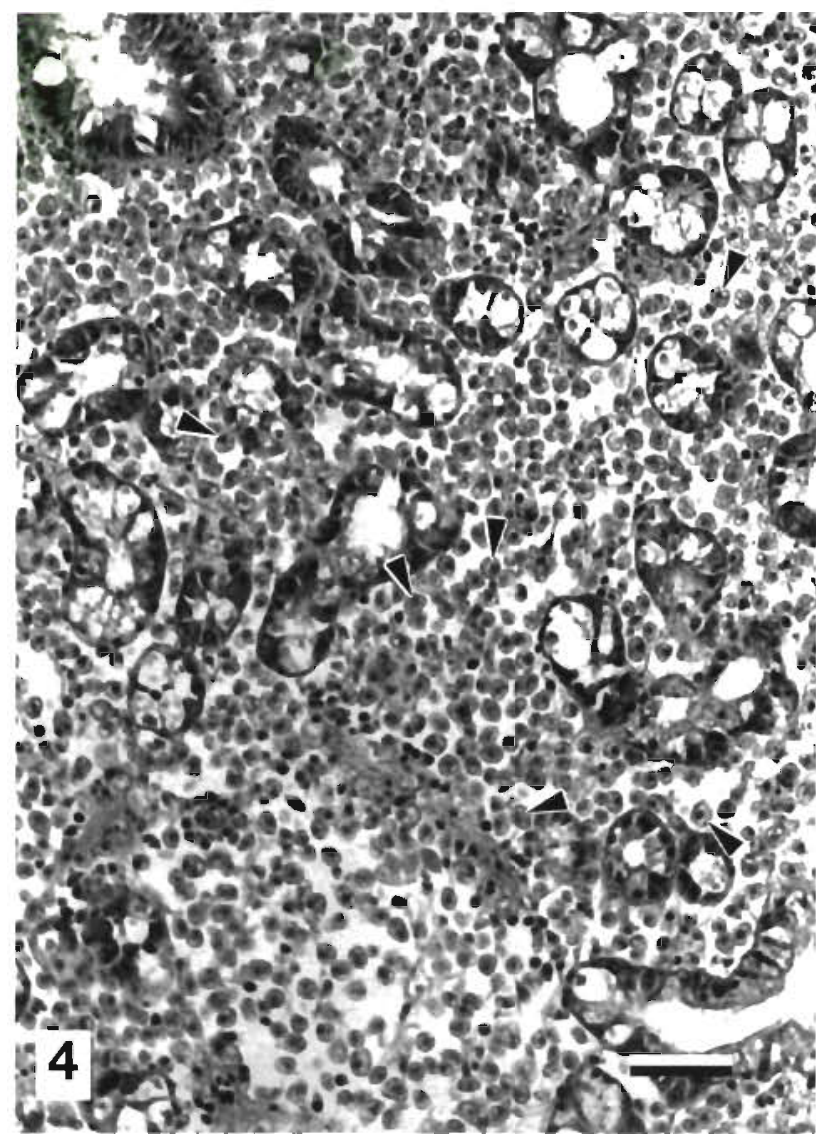

Fig. 4. Patinopecten yessoensis infected with Perkinsus qugwadi. Histological section (stained with hematoxylin and eosin) of the digestive gland of scallops very heavily infected with $P$. qugwadi (arrowheads). In comparison to heavily infected scallops (Figs. 2 \& 3), scallops categorised as very heavy (VH) had more parasite cells than host tissue present in most histological sections of the digestive gland and gonad (not shown). Scale bar $=50 \mu \mathrm{m}$

Canada, e-mail: kenchingtone@mar.dfo-mpo.gc.ca) for analysis. There were no detectable restriction fragment length polymorphisms observed in 9 unique digests of the nuclear $18 \mathrm{~S}$ rRNA gene (cf. Kenchington et al. 1993, 1994, Rice et al. 1993) between 2 weathervane scallops, 3 Japanese scallops, and 3 specimens believed to be hybrids. Consequently, another region of the rRNA gene bound by and including the internally transcribed spacers (ITS I, 5.8S, ITS II) was sequenced. The sequence of the 5.8S rRNA gene was conserved with no differences between the species except for 1 hybrid which had 1 base change from the others. However, there was considerable variation within both ITS regions of the Japanese scallop. In contrast, the weathervane scallop was more conservative. The hybrids were also variable and showed a greater similarity to the weathervane scallop (12 alignment differences) than to the Japanese scallop (84 alignment differences). Dr Kenchington (pers. comm.) concluded that they appeared to be true genetic hybrids. Also the hybrids proved more resistant to Perkinsus qugwadi than purebred Japanese scallops that had no history of exposure to $P$. qugwadi.

Perkinsus qugwadi is related to a group of parasites that are pathogenic to many species of molluscs around the world (Goggin \& Lester 1995). One species, Perkinsus marinus, is a significant pathogen of eastern oysters Crassostrea virginica on the east and south coasts of the United States (Andrews 1996, Ray 1996, Soniat 1996), and has a significant detrimental impact on eastern oyster resources in Chesapeake Bay (Andrews 1988, Burreson \& Calvo 1996). Burreson (1991) indicated that one approach to developing resistant oysters is through a selective breeding program in which surviving oysters from disease enzootic areas are selected and bred over successive generations in an attempt to decrease disease-induced mortality. Although Burreson (1991) demonstrated that natural exposure to $P$. marinus over many generations in an enzootic area appeared to decrease susceptibility of eastern oysters to initial challenge, no increase in resistance was found in eastern oysters exposed to a natural condition of continued disease pressure. Thus, despite over $30 \mathrm{yr}$ of known disease activity, the eastern oysters have developed neither tolerance nor disease resistance to $P$. marinus (Mann et al. 1991). In the present study, progeny of scallops that survived an epizootic of $P$. qugwadi not only showed a significant decrease in susceptibility to $P$. qugwadi during an initial challenge (laboratory study), siblings also had increased resistance over unselected stocks when exposed under natural conditions (field study). Burreson (1991) speculated that eastern oysters from areas enzootic to $P$. marinus may not have acquired resistance to this parasite because of ongoing contributions to the oyster population in enzootic areas by upriver and uninfected (unselected) oyster stocks. This scenario does not occur with cultured scallops in B.C. All Japanese scallop stocks in the province are derived from hatchery-produced seed where there is control over seed production.

The observation of differences in prevalence and intensity of infection of Perkinsus qugwadi in different stocks of Japanese scallops suggests that genetic variation in disease resistance occurs in scallops of the genus Patinopecten. Gaffney \& Bushek (1996) indicated that the rate of evolution of resistance in disease challenged eastern oyster populations has been modest in some cases (e.g. resistance to MSX, specifically efforts at Rutgers University to select Haplosporidium nelsoni resistant strains by manipulative breeding have resulted in some improvement in survival in response to challenge after 25 yr of research and over 8 generations of selection [Mann et al. 1991]) and dra- 
matic in others (e.g. rapid evolution of resistance to Malpeque Bay disease). The results presented in this paper indicate that the scallops showed a dramatic increase in resistance to $P$. qugwadi. Japanese scallops that survived a single epizootic of $P$. qugwadi produced progeny that had a marked difference in resistance to infection.

Meyers et al. (1991) indicate that one method of reducing losses of bivalve stocks to disease is to utilise species not susceptible to local disease. Several scientific investigations have established that the Pacific oyster Crassostrea gigas is more resistant to Perkinsus marinus than the eastern oyster (Farley et al. 1991, Meyers et al. 1991, Barber \& Mann 1994, Burreson et al. 1994, Chu 1996). Unfortunately, the Pacific oyster is much less tolerant to environmental conditions of low salinities (<20 ppt) and high temperatures $\left(>15^{\circ} \mathrm{C}\right)$ prevailing in eastern oyster habitat (Barber \& Mann 1994, Chu 1996) and hybrids between Pacific and eastern oysters are not viable (Allen et al. 1993). Unlike Pacific and eastern oysters, weathervane and Japanese scallops produce viable hybrids. Although the hybrid stock was more resistant to infection and the lethal effects of $P$. qugwadi than naive Japanese scallops, their resistance was similar to that of the selected purebred Japanese scallops. Because the hybrid and selected purebred Japanese scallop stocks shared their maternal lineage (cohort $\mathrm{S} 10$ that survived a $P$. qugwadi epizootic), it cannot be ascertained if hybrid status alone would confer protection or if protection was solely attributed to maternal effects.

The lower prevalence and intensity of infection in the selected and hybrid scallops, in both laboratory and field exposure experiments, suggests that the ability to resist morbidity as a result of infection was increased. Also, the ability to control the infection appeared to be enhanced, as indicated by the heightened haemocytic response observed in the selected and hybrid scallops in comparison to the naive group. Regardless of the mechanisms involved, the rapid production of selected and hybrid scallops that are resistant to Perkinsus qugwadi has provided the scallop culture industry in B.C. an opportunity to develop. In accordance with the statement of Gaffney \& Bushek (1996) that from an 'evolutionary perspective, the interplay between host and pathogen is now realised to be more complex than originally thought', we acknowledge that our approach was very simplistic but as long as this approach continues to work, the questions of how and why will be viewed as academic to the developing industry.

Acknowledgements. We are grateful to Island Scallops Ltd for providing scallop stocks used in the laboratory experinents and for assistance in conducting the field exposure experi- ments. Barbara L. Bunting of Island Scallops Ltd, provided information on the scallop stocks and current commercial production practices. Jane Osborne and Carolyn J. Bird of the Institute of Marine Biosciences, NRC, Halifax, N.S., extracted, sequenced and assisted in the analysis of the scallop DNA. We also thank Paige Eveson for technical assistance with the statistical analysis of the data.

\section{LITERATURE CITED}

Allen SK, Gaffney PM. Scarpa J, Bushek D (1993) Inviable hybrids of Crassostrea virginica (Gmelin) with C. rivularis (Gould) and C. gigas (Thunberg). Aquaculture 113:269-289

Andrews JD (1988) Epizootiology of the disease caused by the oyster pathogen Perkinsus marinus and its effects on the oyster industry. Am Fish Soc Spec Publ 18:47-63

Andrews JD (1996) History of Perkinsus marinus, a pathogen of oysters in Chesapeake Bay 1950-1984. J Shellfish Res 15:13-16

Barber BJ, Mann R (1994) Growth and mortality of eastern oysters, Crassostrea virginica (Gmelin 1791), and Pacific oysters, Crassostrea gigas (Thunberg 1793) under challenge from the parasite, Perkinsus marinus. J Shellfish Res 13:109-114

Bernard FR (1983) Catalogue of the living Bivalvia of the eastern Pacific Ocean: Bering Strait to Cape Horn. Can Spec Publ Fish Aquat Sci 61:1-102

Bernard FR, Cai YY, Morton B (1993) Catalogue of the living marine bivalve molluscs of China. Hong Kong University Press, Hong Kong

Blackbourn J, Bower SM, Meyer GR (1998) Perkinsus qugwadi sp. nov. (incerte sedis), a pathogenic parasite of Japanese scallops, Patinopecten yessoensis, cultured in British Columbia, Canada. Can J Zool 76:942-953

Bower SM, Blackbourn J, Meyer GR (1998) Distribution, prevalence and pathogenicity of the protozoa Perkinsus qugwadi in Japanese scallops, Patinopecten yessoensis, cultured in British Columbia, Canada. Can J Zool 76: 954-959

Burreson EM (1991) Effects of Perkinsus marinus infection in the eastern oyster, Crassostrea virginica: I. susceptibility of native and MSX-resistant stocks. J Shellfish Res 10: $417-423$

Burreson EM, Calvo LMR (1996) Epizootiology of Perkinsus marinus disease of oysters in Chesapeake Bay, with emphasis on data since 1985. J Shellfish Res 15:17-34

Burreson EM, Mann R, Allen SK (1994) Field exposure of triploid Crassostrea gigas to Haplosporidium nelsoni (MSX) and Perkinsus marinus (dermo) in the lower Chesapeake Bay. J Shellfish Res 13:293 (abstract)

Chu FLE (1996) Laboratory investigations of susceptibility, infectivity, and transmission of Perkinsus marinus in oysters. J Shellfish Res 15:57-66

Farley CA, Plutschak DL, Krantz GE (1991) Crassostrea gigas disease exposure to Haplosporidium nelsoni and Perkinsus marinus in Chesapeake Bay waters. J Shellfish Res 10: 306-307 (abstract)

Gaffney PM, Bushek D (1996) Genetic aspects of disease resistance in oysters. J Shellfish Res 15:135-140

Goggin CL, Lester RJG (1995) Perkinsus, a protistan parasite of abalone in Australia: a review. Mar Fish Res 46:639-646

Grau G (1959) Pectinidae of the eastern Pacific. Allan Hancock Pac Exp 23:1-308

Hastie TJ, Pregibon D (1992) Generalized linear models. In: Chambers JM, Hastie TJ (eds) Statistical models in S, 1st edn. Wadsworth \& Brooks/Cole Computer Science Series, 
Pacific Grove, CA, p 195-247

Kenchington E, Naidu KS, Roddick DL, Cook DI, Zouros E (1993) The use of biochemical genetic markers to discriminate between adductor muscles of the Sea Scallop (Placopecten magellanicus) and the Iceland Scallop (Chlamys islandica). Can J Fish Aquat Sci 50:1222-1228

Kenchington E, Roddick D, Singh R, Bird C (1994) Analysis of the small-subunit rRNA gene sequences from six families of molluscs. J Mar Biotechnol 1(4):215-217

Mann R, Burreson EM, Baker PK (1991) The decline of the Virginia oyster fishery in Chesapeake Bay: considerations for introduction of a non-endemic species, Crassostrea gigas (Thunberg 1793). J Shellfish Res 10:379-388

McCullagh P, Nelder JA (1989) Generalized linear models, 2nd edn. Chapman and Hall, London

Meyers JA, Burreson EM, Barber BJ, Mann R (1991) Susceptibility of diploid and triploid Pacific oysters, Crassostrea gigas (Thunberg 1793) and eastern oysters, Crassostrea virginica (Gmelin 1791), to Perkinsus marinus. J Shellfish Res 10:433-437

Motavkin PA (1986) Primorskiy grebeshok; Japanese scallop Mizuhopecten yessoensis (Jay) [The yezo scallop or Japanese common scallop, Mizuhopecten yessoensis (Jay)]. DVNTS an SSSR, Vladivostok (Institute of Marine Biology, Vladivostok: Far East Science Centre, Academy of the USSR). In Russian, translated in 1990 and available from

Editorial responsibility: Albert Sparks,

Seattle, Washington, USA the Canadian Institute for Science and Technical Information, National Research Council, Ottawa, Ontario, K1A 0S2, Canada, in series Canadian Translation of Fisheries and Aquatic Sciences; No. 5501

Ray SM (1966) A review of the culture method for detecting Dermocystidium marinum, with suggested modifications and precautions. Proc Natl Shellfish Assoc 54:55-69

Ray SM (1996) Historical perspective on Perkinsus marinus disease of oysters in the Gulf of Mexico. J Shellfish Res 15: 9-11

Rice EL, Roddick D, Singh RK (1993) A comparison of molluscan (Bivalvia) phylogenies based upon palaeontological and molecular data. Mol Mar Biol Biotechnol 2:137-146

Saunders RG, Heath WA (1994) New developments in scallop farming in British Columbia. Bull Aquacult Assoc Can $94(3): 3-7$

Shaw BL, Battle HI (1957) The gross and microscopic anatomy of the digestive tract of the oyster Crassostrea virginica (Gmelin). Can J Zool 35:325-347

Silina AV, Pozdnyakova LA, Kijashko SI (1988) Microsculpture, chemical and isotope composition of the shell of a scallop Patinopecten caurinus (Pectinida, Pectinidae). Zool Zh 67:340-345 (in Russian with English summary)

Soniat TM (1996) Epizootiology of Perkinsus marinus disease of eastern oysters in the Gulf of Mexico. J Shellfish Res 15: $35-43$

Submitted: April 30, 1998; Accepted: December 14, 1998 Proofs received from author(s): April 15, 1999 